\title{
P-93
}

\section{Antioxidant Properties of Standardized Extracts and Fractions of Morinda Citrifolia Linn. Fruit}

\author{
Hooi-Kheng Beh*, Lay-Jing Seow, Mohd Zaini Asmawi and Zhari Ismail
}

School of Pharmaceutical Sciences, Universiti Sains Malaysia, Penang, Malaysia; E-mail: khengbeh@yahoo.com

Morinda citrifolia Linn. (Rubiaceae) locally known as Mengkudu besar is the plant reported to have a broad range of medicinal use. The purpose of this study is to evaluate antioxidant properties of standardized fruit extracts and fractions using 1,1diphenyl-2-picrylhydrazyl scavenging activity and $\beta$-carotene-linoleate assays and to identify the major chemical constituents of the active fractions using GC-MS analysis. The total phenolics and total flavonoids content of the fruit were also evaluated. The result showed the ethyl acetate fraction of the fruit possessed the highest bleaching ability with $\mathrm{EC}_{50}$ value of 164.09 $\mathrm{ug} / \mathrm{mL}$ and the fraction was found to have the highest antioxidant property $(83.46 \pm 0.27 \%$ at $500 \mathrm{ug} / \mathrm{mL}) \mathrm{in} \beta$-carotenelinoleate system. Ethyl acetate fraction also has the highest total phenolics content $(167.71 \pm 5.30 \mathrm{ug} / \mathrm{mL} \mathrm{GAE})$ and total flavonoids content $(22.30 \pm 1.22 \mathrm{ug} / \mathrm{mL}$ QE). Three major compounds present in ethyl acetate fraction were identified as octanoic acid (16.45\%), pentanoic acid (10.12\%) and 2,4-bis(1,1-dimethylethyl) phenol (9.50\%). In conclusion, the ethyl acetate fraction of Morinda citrifolia fruit can be an alternative source of polyphenolics with potent antioxidant activities.

Keywords: Morinda citrifolia Linn., standardized extracts and fractions, antioxidant, GC-MS. 